\title{
Divergence of Tissue-Memory T Cells: Distribution and Function-Based Classification
}

\author{
Shiki Takamura \\ Department of Immunology, Kindai University Faculty of Medicine, Osaka-Sayama, Osaka 589-8511, Japan \\ Correspondence: takamura@med.kindai.ac.jp
}

Tissue-resident memory T cells (Trm) comprise the majority of memory cells in nonlymphoid tissues and play a predominant role in immunity at barrier surfaces. A better understanding of Trm cell maintenance and function is essential for the development of vaccines that confer frontline protection. However, it is currently challenging to precisely distinguish Trm cells from other T cells, and this has led to confusion in the literature. Here we highlight gaps in our understanding of tissue memory and discuss recent advances in the classification of Trm cell subsets based on their distribution and functional characteristics.

M emory $\mathrm{T}$ cells are established after an infection or vaccination and have the ability to mediate faster and stronger responses to subsequent antigen challenge. Until recently, memory $\mathrm{T}$ cells were broadly divided into two main subsets, effector memory $\mathrm{T}$ (Tem) and central memory $\mathrm{T}$ cells $(\mathrm{Tcm})$. Tem cells lack the expression of a lymph node (LN) homing receptor CCR7 and can exert immediate effector functions upon restimulation, whereas $\mathrm{Tcm}$ cells express CCR7 and generally do not express immediate effector functions (Sallusto et al. 1999). Tem and Tcm cells also differ in their tissue distribution: Tem cells are abundant in nonlymphoid tissues (NLTs) (Masopust et al. 2001; Reinhardt et al. 2001), whereas Tcm cells predominate in the secondary lymphoid organs (SLOs) such as spleen and LN. Recently, it has been discovered that most memory cells in the NLTs are not actually Tem cells, but rather a distinct third population of memory cells. Cells in this third population reside permanently within tissues and have therefore been termed tissue-resident memory $\mathrm{T}$ cells (Trm) (Gebhardt et al. 2009; Masopust et al. 2010; Wakim et al. 2010; Teijaro et al. 2011). This led to the current paradigm of three memory subpopulations defined by their differential migratory properties: two circulatory populations (Tcm cells through the SLOs and Tem cells through the NLTs) and a resident population (Trm cells in NLTs and SLOs) (Takamura 2018). A recent study has proposed a further subdivision of Tem cells based on their expression of CX3CR1: CX3CR1 ${ }^{\text {hi }}$ cells exhibit a Tem cell phenotype but are present only in the blood (i.e., absent in SLOs and NLTs), whereas CX3CR $1^{\text {int }}$ cells, termed as peripheral memory (Tpm), behave like classical Tem cells (i.e., circulate between tissues and blood). Because of the overlapping features of classical Tem and Tpm cells, we have used the classical Tem-cell

Editors: David Masopust and Rafi Ahmed

Additional Perspectives on T-Cell Memory available at www.cshperspectives.org

Copyright (C) 2020 Cold Spring Harbor Laboratory Press; all rights reserved; doi: 10.1101/cshperspect.a037762

Cite this article as Cold Spring Harb Perspect Biol 2020;12:a037762 


\section{S. Takamura}

designation for tissue-circulatory memory $\mathrm{T}$ cells in this review.

Trm cells play a central role in controlling infections at barrier surfaces. They occupy tissue-specific niches without recirculating and can be divided into subsets that are related to their location and function. However, a precise understanding of the biology of Trm cell subsets has been hampered by the limited fidelity of surface markers and methodologies that validate residency, and the complexity of different models of infection and immunization. For example, although intravascular (i.v.) staining labels blood cell contaminants in the tissues (Anderson et al. 2012), it cannot distinguish Trm from Tem cells. Moreover, well-established markers of Trm cells (CD69 and/or CD103) are not present on all Trm cell populations (Steinert et al. 2015; Kumar et al. 2017), potentially resulting in Trm cell subpopulations being missed in previous studies. Parabiosis studies in which surgery is used to establish a shared anatomic circulation between host and partner is a reliable method in excluding partner-derived circulatory populations, but is incapable of discriminating hostderived Tem cells from nonmigrating host Trm cells (Takamura and Kohlmeier 2019; Takamura et al. 2019). Furthermore, the functions and features of Trm cells differ depending on their localization within the same tissue (epithelium vs. stroma), and this localization is influenced by the route of infection/vaccination (systemic vs. local), the nature of the pathogens used (acute vs. chronic), and the experimental conditions (such as conventional specific pathogen-free vs. germfree vs. animals with diverse microbial experience). Therefore, careful consideration of the pros and cons of each experimental technique and model system is required to fully understand tissue memory diversity. Herein we will summarize the current knowledge of tissue memory diversity, given these technological limitations.

\section{EPITHELIAL Trm CELLS}

Epithelial tissues, comprised of sheets of epithelial cells, cover the surfaces of barrier tissues including the skin, gastrointestinal, respiratory, and urogenital tracts, as well as hollow parts of exocrine and endocrine glands. Basement membrane underlies the bottom layers of epithelial cells, thereby providing physiological and environmental separation of the epithelium from the stromal tissues (dermis, lamina propria, lung interstitium, etc.). Because epithelial tissues are avascular and essentially lack lymphatic drainage, memory $\mathrm{T}$ cells maintained in these tissues do not return to the circulation under steadystate conditions and are classified as Trm cells (note that a low level of traffic between the epithelium and stroma has been observed [Dijkgraaf et al. 2019; Thompson et al. 2019]). Epithelial Trm cells include cells in the skin epidermis (Gebhardt et al. 2009; Jiang et al. 2012), the intestinal intraepithelial lymphocyte (IEL) compartments (Sheridan et al. 2014; Bergsbaken and Bevan 2015), the lung airways (Hogan et al. 2001), the epithelium of the female reproductive tract (FRT) (Shin and Iwasaki 2012), and the salivary glands (Smith et al. 2015; Thom et al. 2015). An overwhelming majority of adoptive immune cells in the epithelium are $\mathrm{CD}^{+}{ }^{+}$Trm cells, although some $\mathrm{CD} 4{ }^{+}$Trm cells are also present (Gebhardt et al. 2011; Kumar et al. 2017).

\section{Intraepithelial Migration}

After being primed in the draining LNs, antigen-specific T cells home to the site of infection/ immunization. Upon entry into the stroma, a fraction of effector $\mathrm{T}$ cells acquire tissue-derived instructions that enable them to traffic through the basement membrane (Fig. 1A). An actindriven morphological change is required for traversing the basement membrane, as $\mathrm{T}$ cells lacking myosin IXb (Myo9b), an F-actin-based cytoskeletal motor protein, fail to enter the epidermal compartment (Moalli et al. 2018). In the case of a localized infection, inflammatory chemokines such as CXCL9 and CXCL10 (ligands for CXCR3) secreted at the site of infection play a key role in inducing cytoskeletal remodeling of effector T cells, thereby promoting intraepithelial migration and subsequent formation of $\mathrm{CD}^{+}$Trm cells in the epithelium (Nakanishi et al. 2009; Mackay et al. 2013; Abboud et al. 2016; Gilchuk et al. 2016; Pizzolla et al. 2017; Caldeira-Dantas et al. 2018). This step may be 
A
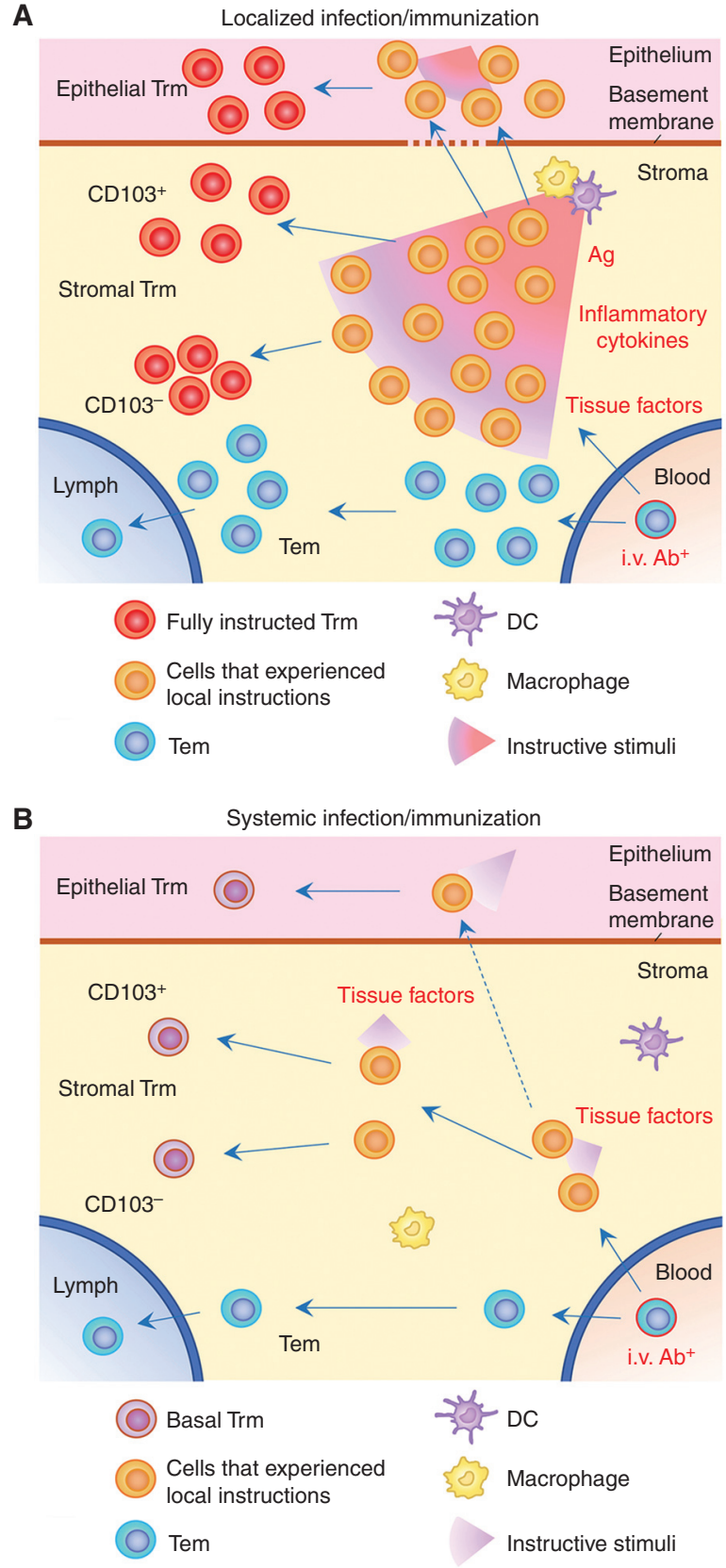

Figure 1. Models of tissue memory diversity. (A) Establishment of tissue-resident memory T cells (Trm) at the site of infection/immunization. Trm precursor T cells $\left(\mathrm{KLRG1}^{-} \mathrm{CX}_{3} \mathrm{CR} 1^{-}\right)$recruited to the stroma receive tissuederived instructive signals, including strong antigenic and inflammatory stimuli. Cells receiving appropriate instruction traffic through the basement membrane and differentiate into a unique population of epithelial Trm cells after receiving additional instructive cues. In the stroma, cells receive differential instructive stimuli and mature into diverse populations of Trm cells, such as the $\mathrm{CD}_{103^{+}}$and $\mathrm{CD} 103^{-}$subpopulations. Cells that did not receive any instructions do not up-regulate master transcription factors and leave the tissues as effector memory T cells (Tem). (B) Establishment of Trm cells at sites distal to infection/immunization sites. Basal levels of tissue instructive cues (e.g., TGF- $\beta$, IL-15, and aryl hydrocarbon receptor [AhR]) promote the establishment of quantitatively and qualitatively distinct populations of Trm cells as compared to their counterparts at the site of infection/immunization. In both cases, only cells in the blood are labeled by intravascular (i.v.) staining. (Ag) antigen, (DC) dendritic cell. 


\section{S. Takamura}

facilitated through the interaction of CD49a (integrin $\alpha 1 \beta 1$ ) with collagen IV, a major component of basement membrane (Topham and Reilly 2018), leading to the preferential accumulation of $\mathrm{CD}_{49 \mathrm{a}^{+}}$Trm cells in some epithelial tissues, such as skin and lung (Ray et al. 2004; Gebhardt et al. 2009; Cheuk et al. 2017). T cells recruited to the stroma of an infection site encounter antigen-presenting cells (APCs), which induce terminal effector differentiation and additional rounds of expansion (McGill et al. 2008, 2010; McGill and Legge 2009; McKinstry et al. 2014). Reactivation with cognate antigen in the stroma also serves as a primary tissue-derived instruction required for Trm cell differentiation and intraepithelial migration (Khan et al. 2016; Takamura et al. 2016; McMaster et al. 2018). This "second hit" up-regulates the expression of the activation marker CD69, which stabilizes the residency of $\mathrm{CD}^{+}$Trm cells by inhibiting sphingosine-1-phosphate receptor 1 (S1P1)mediated tissue egress (Shiow et al. 2006; Mackay et al. 2015a). A second antigen hit also induces the activation and conformational change of various integrins, such as CD103 and CD49a, which mediate firm interactions with their respective ligands, E-cadherin and collagen, in the epithelium. Because regional reactivation of $\mathrm{CD}^{+} \mathrm{T}$ cells occurs even when MHC class I molecules are down-regulated on virus-infected cells (Lauron et al. 2019), professional APCs, such as $\mathrm{CD}_{103}{ }^{+}$dendritic cells (DCs), and monocyte-derived macrophages that acquire and cross-present viral antigens at the site of infection, also contribute to this process (Wakim et al. 2015; Desai et al. 2018). Importantly, the interaction of effector $\mathrm{CD}^{+} \mathrm{T}$ cells with APCs at the site of infection is highly competitive (Muschaweckh et al. 2016) and selects for $\mathrm{CD}^{+}$Trm cells expressing high-affinity T-cell receptors (TCRs) (Frost et al. 2015). Thus, local antigen encounter is vital for shaping the local repertoire of $\mathrm{CD}^{+}$Trm cells in the epithelium.

Although circulating $\mathrm{T}$ cells have extremely limited access to uninflamed epithelial tissues under steady-state conditions (Klonowski et al. 2004), there is a basal level of recruitment of tissue-imprinted $\mathrm{T}$ cells that is mediated by con- stitutively expressed chemokines in the epithelium. These include cutaneous T-cell-attracting chemokine (CTACK) expressed by epidermal keratinocytes (Morales et al. 1999), and CCL25 expressed by intestinal epithelial cells (Kunkel et al. 2000). We, and others, have demonstrated that basal levels of inflammatory chemokines, such as CXCR3 ligands, are also expressed in the lung airways presumably because of continuous exposure to airborne contaminants, which facilitates the basal recruitment of tissue-circulating $\mathrm{CD}^{+}$Tem cells into the epithelium (Slütter et al. 2013; Takamura et al. 2019). Such tissue-specific basal pathways potentially explain a broad distribution of Trm cells at the remote epithelial sites following systemic infection (Fig. 1B; Steinert et al. 2015; Milner et al. 2017). It should be emphasized, however, that epithelial Trm cells established through basal recruitment mechanisms are far less robust than, and phenotypically distinct from, Trm cells generated by local infection (Sheridan et al. 2014; Takamura et al. 2016). Thus, it is reasonable to speculate that Trm cells established in the same location, but in the presence or absence of local infection, will have distinct functional capacities (Fig. 1; Takamura and Kohlmeier 2019).

It is now appreciated that the topical administration of chemokines, or the induction of antigen-independent inflammation, is sufficient to recruit circulating (memory-precursor) effector $\mathrm{CD}^{+} \mathrm{T}$ cells to the epithelium and establish epithelial Trm cells, even in the absence of cognate antigen, a strategy referred to as "primeand-pull" (Mackay et al. 2012; Shin and Iwasaki 2012). This strategy is extremely efficient in certain epithelial tissues, such as the skin and vagina, where preexisting niches are available for $\mathrm{CD}^{+}$Trm cells to establish residency (Takamura 2018). For example, skin epidermal $\mathrm{CD}^{+}{ }^{+}$Trm cells become established in niches previously occupied by dendritic epidermal $\mathrm{T}$ cells (DETCs) (Zaid et al. 2014). In contrast, we and others have demonstrated that lung is a unique tissue where simple prime-and-pull strategies fail to establish $\mathrm{CD}^{+}$Trm cells because of a lack of appropriate niches (Takamura et al. 2016; McMaster et al. 2018). Instead, a combination of local inflammation and cognate 
antigen in the presence of antigen-specific $\mathrm{CD} 8^{+}$ $\mathrm{T}$ cells in the circulation (prime-and-pull plus cognate antigen) leads to immune-mediated tissue damage, which creates de novo Trm cell niches associated with tissue damage and repair (repair-associated memory depots [RAMDs]). These niches subsequently promote lung $\mathrm{CD}^{+}$ Trm cell residency.

Similarly, targeting antigen presentation to hepatocytes effectively traps circulating antigenspecific $\mathrm{CD}^{+} \mathrm{T}$ cells within the liver sinusoid and promotes Trm cell formation, a strategy termed as "prime-and-trap" (Fernandez-Ruiz et al. 2016). In this case, activation but not local antigen presentation is essential for the cells to differentiate into Trm cells (Holz et al. 2018). Given the differences in microenvironmental structures and instructive signals necessary for Trm cell formation in each tissue, development of tissue-specific vaccination strategies is likely required.

\section{Adaptation of Epithelial Trm Cells}

Following intraepithelial migration, T cells receive additional tissue-specific instructive cues that promote Trm cell maturation (adaptation) (Fig. 1A). These include activation signals via cognate antigen and/or inflammatory cytokines, and other factors such as TGF- $\beta$, IL-15, and AhR ligands. Although activation signals sustain the expression of CD69, which helps retain the cells in the epithelium through the inhibition of S1P1, CD69 expression is not essential for retention as epithelial tissues lack lymphatic drainage. Consistent with this, there is only a partial reduction in the formation of epithelial Trm cells in the absence of CD69 (Mackay et al. 2015a; Takamura et al. 2016; Walsh et al. 2019). However, activation-induced events do play an as-yet-undefined cell-intrinsic role in maintaining cells in the tissues, as nearly all $\mathrm{CD}^{-} 9^{-}$cells (presumably nonactivated) in this tissue exhibit short-lived effector phenotypes $\left(\mathrm{KLRG}^{+}\right.$ $\mathrm{CD}_{127^{-}}$) and are committed to die after antigen clearance (Sheridan et al. 2014). In some tissues, basal levels of inflammatory cytokines produced in the epithelium or cross-reactive antigens seem to be sufficient to induce maturation in some cells as epithelial Trm cells can be formed even in the absence of local infection (Masopust et al. 2010; Casey et al. 2012). These (antigennonspecific) activation signals are more prominent under conditions where there is a diverse infection history and can result in substantial numbers of epithelial Trm cells (Beura et al. 2016).

The latent (inactivated) form of TGF- $\beta$ is constitutively produced at basal levels in most epithelial/stromal tissues. This latent form of TGF- $\beta$ can be activated through the actions of the integrins $\alpha v \beta 6$ and $\alpha v \beta 8$ expressed on various cell types in the mucosa, such as keratinocytes, DCs, macrophages, and regulatory $\mathrm{T}$ (Treg) cells (Wakim et al. 2015; Worthington et al. 2015; Mohammed et al. 2016; Kelly et al. 2018; Hirai et al. 2019). The active form of TGF$\beta$ is a critical factor for the up-regulation of CD103 (integrin $\alpha E 7$ ), which facilitates retention of Trm cells within the epithelium through the binding to E-cadherin, a component of epithelial tight junctions (Pauls et al. 2001). Consequently, epithelial Trm cells are highly enriched for expression of CD103 as compared to memory $\mathrm{T}$ cells in the stroma and circulation. CD103 could be considered a reliable marker for Trm cells; however, small numbers of CD103 $\mathrm{CD}^{+}$Trm cells are also present in the epithelium, and a CD103 deficiency does not result in the global absence of epithelial Trm cells (Lee et al. 2011; Mackay et al. 2013; Sheridan et al. 2014). These data suggest that the tethering role of CD103 could be compensated for, in part, by other adhesive molecules, such as CCR8 (McCully et al. 2018). Importantly, studies relying exclusively on CD103 to identify Trm cells will underestimate the overall populations of Trm cells in tissues. Interestingly, while a majority of epithelial $\mathrm{CD}^{+}$Trm cells express CD103, most $\mathrm{CD}^{+}$Trm cells in these tissues largely lack the expression of this molecule (Watanabe et al. 2015; Kumar et al. 2017; Romagnoli et al. 2017). Because reactivation of $\mathrm{CD} 4^{+}$Trm cells requires interaction with $\mathrm{MHC}$ class $\mathrm{II}^{+}$ APCs, it is tempting to speculate that the lack of CD103 may be important in retaining the migratory (motional) flexibility of $\mathrm{CD} 4^{+}$Trm cells to access to the proximal lymphoid struc- 


\section{S. Takamura}

tures where efficient APC T-cell interactions occur during secondary infections. In contrast to the conventional epithelial tissues, $\mathrm{CD}^{+}$Trm cells in the liver sinusoid entirely lack the expression of CD103, presumably reflecting the lack of tight junctions in the sinusoidal epithelium (Fernandez-Ruiz et al. 2016).

IL-15 is also known to be important for the maturation and maintenance of epithelial Trm cells in some tissues, such as the skin, salivary gland, and kidney (Schenkel et al. 2016). Upon arrival in the epithelium, memory precursor $\mathrm{CD}^{+} \mathrm{T}$ cells receive IL-15 signals that prevent TGF- $\beta$-mediated down-regulation of T-bet, thereby promoting increased survival (Mackay et al. 2015b). In the skin, signaling through IL15 and the AhR is essential for the long-term maintenance of both epidermal $\mathrm{CD}^{+}$Trm cells and DETCs, thereby resulting in competition for the same survival niche (Kadow et al. 2011; Zaid et al. 2014). However, in several other epithelial tissues, such as the lung, gut, and FRT, $\mathrm{CD}^{+}$Trm cells can be generated and maintained in the absence of IL-15, highlighting the heterogeneity of Trm cell development in different tissues (Verbist et al. 2011; Schenkel et al. 2016).

\section{Unique Features of Epithelial Trm Cells}

It is well established that epithelial Trm cells differ significantly in morphology, phenotype, function, and maintenance, compared to their stromal counterparts. The best example is in the skin. Epidermal CD8 ${ }^{+}$Trm cells in the skin display a highly dynamic dendritic morphology, whereas dermal Trm cells display a more amoeboid shape. The dendritic morphology of epidermal CD8 ${ }^{+}$Trm cells is consistent with their need to actively crawl between keratinocytes to sense rare virally infected cells and trigger an innate interferon (IFN) response in response to cognate antigen (Ariotti et al. 2012, 2014; Schenkel et al. 2013, 2014; Dijkgraaf et al. 2019). Epidermal CD8 ${ }^{+}$Trm cells are further divided into two distinct subpopulations based on CD49a expression: $\mathrm{CD} 49^{+} \mathrm{CD} 103^{+} \mathrm{CD}^{+}$ Trm cells are poised for the production of IFN- $\gamma$ and cytolytic molecules and tend to accumulate in lesional vitiligo, whereas CD $49^{-} \mathrm{CD}_{103}{ }^{+} \mathrm{CD} 8{ }^{+}$Trm cells preferentially produce IL-17 and potentially contribute to the development of psoriasis (Cheuk et al. 2017). In both cases, epidermal Trm cells excel in cytokine production relative to their dermal counterparts. Higher cytotoxic T-cell (CTL) activity is also characteristic of intestinal epithelial Trm cells (Booth et al. 2019), although this may not be the case in a model of systemic infection where cognate antigens are absent in the intestinal epithelium (Beura et al. 2015). $\mathrm{CD}^{+}$Trm cells in the IEL compartment are also unique. These cells maintain effector-like semi-activated status enabling them to rapidly regain function. This semi-activated state is tightly regulated by a reduced metabolic capacity mediated by alterations in mitochondrial membrane composition. The regulation of metabolic activity in this case is thought to be a mechanism to prevent immunopathology, a feature that may be unique to IEL Trm cells (Konjar et al. 2018). Trm cells in the epithelial tissues are also known to metabolically adapt to their environment. As the skin and intestinal epithelia are rich in fatty acid but limited in other nutrients, epithelial Trm cells in these tissues appear to utilize exogenous fatty acid to support their differentiation, longevity, and protective function (Fahrer et al. 2001; Pan et al. 2017; Bachem et al. 2019).

The function and maintenance of lung airway $\mathrm{CD}^{+}$Trm cells is also unique. These cells progressively lose the expression of CD11a (LFA-1) upon migration into this tissue, thereby losing cell contact-mediated cytolytic activity (Hogan et al. 2001; Ely et al. 2006; Kohlmeier et al. 2007). Yet, airway CD ${ }^{+}$Trm cells are sufficient to confer heterosubtypic protection against influenza challenge through the rapid and robust production of IFN- $\gamma$ upon recall (McMaster et al. 2015). Recently, we have demonstrated that environmental cues in the lung airways drive huge transcriptional and epigenetic changes in airway $\mathrm{CD}^{+}$Trm cells, including the induction of genes associated with the integrated stress response (ISR), which shortens the life span of the cells (Hayward et al. 2020). Together with the cell-extrinsic factors (e.g., bio- 
Tissue Memory Diversity

physical removal by barrier function of airway mucosa), $\mathrm{CD}^{+}$Trm cells in the lung airways have a relatively short half-life $(\sim 2$ weeks $)$, necessitating the continual recruitment of $\mathrm{CD}^{+}$ T-cell memory to sustain their numbers (Ely et al. 2006; Zammit et al. 2006). This is consistent, at least in part, with previous data suggesting that populations of memory $\mathrm{CD}^{+} \mathrm{T}$ cells in the lung (including Tem and Trm cells in the interstitium and airways) are continuously replenished by Tem cells from the circulation (implying Tem to Trm cell conversion) in an antigen-independent manner (Slütter et al. 2017). However, we have undertaken a precise characterization of lung memory subsets and demonstrated that a majority of airway $\mathrm{CD}^{+}$ Trm cells are seeded by the Trm cell pool maintained in RAMD niches in the lung interstitium, with only a minimal contribution by Tem cells (Takamura et al. 2019). This study also demonstrated that $\mathrm{CD} 8{ }^{+}$Trm cells in the lung interstitium are maintained independently from Tem cells (minimum, if any, Tem to Trm cell conversion). This highlights the importance of the precise classification and separation of tissue memory subtypes to better understand their biology (Takamura and Kohlmeier 2019).

In other tissues, Tem cells may be essential for Trm cell maintenance. In the mouse model of murine cytomegalovirus (MCMV) infection, antigen-specific memory $\mathrm{CD}^{+} \mathrm{T}$ cells that undergo memory inflation (antigen-driven expansion of the circulatory memory during the late stages of infection) are stably maintained in the epithelium of the salivary gland as Trm cells, while the number of noninflating Trm cells significantly decline over time along with a decline in the Tem cell population in the circulation, suggesting the inflationary Tem cell-dependent maintenance of epithelial Trm cells in the salivary gland (Smith et al. 2015; Thom et al. 2015). Furthermore, Tem cell-dependent and TGF- $\beta$ independent maintenance of $\mathrm{CD}^{+}$Trm cell IELs is also evident in animals chronically infected with lymphocytic choriomeningitis virus (LCMV) (Zhang and Bevan 2013), suggesting the role of repeated antigen encounter (presumably in the circulation) in promoting Tem to Trm cell conversion.

\section{STROMAL MEMORY T CELLS (INCLUDING BOTH Trm AND Tem CELLS)}

Stromal tissues (e.g., dermis, intestinal lamina propria, and lung interstitium) that underlie the basement membrane are mainly composed of fibroblasts and extracellular matrix (a network of elastin and collagen fibers), and harbor a variety of immune cell populations, including Trm and Tem cells. Many of these cells are distributed in organized lymphoid structures but are also found diffused throughout the stroma. Both $\mathrm{CD}^{+}$and $\mathrm{CD} 8^{+}$Trm cells are found in these tissues, although $\mathrm{CD} 4^{+}$Trm cells generally dominate. Because blood and lymphatic vessels are rich in the stroma, Trm cells in the stroma need to continuously silence tissue egression programs for their long-term maintenance. It is important to note here that both tissue-circulating Tem and bona fide Trm cells are not labeled with i.v.-injected antibodies (Fig. 1). This highlights the need for combining additional strategies to distinguish these populations. Furthermore, there is strict anatomical compartmentalization between Tem and Trm cells in the stroma, as $\mathrm{CD} 8^{+}$Trm cells are predominantly deposited in their specific niches at the site of previous infection while $\mathrm{CD}^{+}$Tem cells are widely diffused throughout the tissue (Takamura et al. 2016). Hence, it is likely that, under steady-state condition, Tem cells traffic through the stromal tissues where local instructive signals are rarely accessible (Fig. 1).

\section{Developmental Bifurcation of Tem and Trm Cells}

Upon entry into the stroma, memory precursor $\mathrm{T}$ cells are subjected to migratory (developmental) signals directing them to either remain in the stroma (including subsequent intraepithelial migration) or leave the tissues as Tem cells (Fig. 1A). These decisions are driven by the acquisition of tissue-derived instructions, including signals through the TCRs, costimulatory molecules, cytokines, and other unknown factors, that trigger the up-regulation of "master" transcription factors, such as Runx3, Hobit, and Blimp-1 (Mackay et al. 2016; Milner et al. 
S. Takamura

2017). Although the critical stimuli that regulate these transcription factors are not fully understood, each of these transcription factors universally instruct retention primarily (but not exclusively) through the repression of KLF2, thereby suppressing the expression of downstream tissue egress molecules, S1P1, CCR7, and CD62L (Skon et al. 2013). The expression of master transcription factors also promotes the up-regulation of CD103 and CD69, which accelerates tissue retention through ligand binding and antagonistic down-regulation of S1P1, respectively (Behr et al. 2018; Milner and Goldrath 2018). Whereas most resident cell populations share a common transcriptional program, biased usage of particular transcription factors is also evident. For example, the formation of $\mathrm{CD} 103^{+} \mathrm{CD}^{+} \mathrm{Trm}$ cells in the lung critically depends on Blimp-1 but not Hobit (Behr et al. 2019). Because Blimp-1 expression is linked to terminal effector differentiation (Kallies et al. 2009; Rutishauser et al. 2009), and antigen recognition potentially down-regulates Hobit expression (van Gisbergen et al. 2012), Blimp-1dependent and Hobit-independent formation of $\mathrm{CD} 103^{+} \mathrm{CD}^{+}$Trm cells might be unique in tissues where the establishment of Trm cells largely relies on a second hit with cognate antigen (Takamura et al. 2016; McMaster et al. 2018). Thus, defining the overall picture of instructive signals and their downstream transcription factors in each tissue will have significant implications for the development of vaccines designed to establish Trm cells in different mucosal sites.

\section{Stromal CD8 ${ }^{+}$Trm Cell Subpopulations}

Accumulating evidence indicates that stromal $\mathrm{CD} 8^{+}$Trm cells are heterologous in terms of their phenotype, localization, and function. In fact, using a parabiosis approach, we have demonstrated that host-derived (noncirculating) $\mathrm{CD}^{+}$Trm cells in the lung stroma include a canonical $\mathrm{CD} 9^{+} / \mathrm{CD} 103^{+}$population and a similarly sized $\mathrm{CD} 9^{+} / \mathrm{CD} 103^{-}$population (Tem cells are excluded from these populations as these are mostly $\mathrm{CD}^{-} 9^{-}$) (Takamura et al. 2016; Takamura and Kohlmeier 2019). The formation of $\mathrm{CD} 103^{+} \mathrm{CD}^{+}$Trm cells strictly de- pends on TGF- $\beta$, as lack of TGF- $\beta$ signaling results in the complete loss of $\mathrm{CD} 103^{+}$Trm cells (Hu et al. 2015). However, as most of the previous studies have not considered $\mathrm{CD} 103^{-} \mathrm{CD} 8^{+}$ $\mathrm{T}$ cells as Trm cells, the biology of these relatively large $\mathrm{CD}_{103^{-}} \mathrm{CD}^{+}$Trm cells is largely unknown. Comparison of Trm cell phenotypes between different epitope-specific $\mathrm{CD} 8^{+} \mathrm{T}$ cells showed that elevated expression of CD103 on $\mathrm{CD}^{+}$Trm cells correlated with weaker activation status, as biased expression of CD103 on influenza virus polymerase (PA)-specific but not nucleoprotein (NP)-specific $\mathrm{CD} 8^{+} \mathrm{T}$ cells is inversely correlated with their expression of PD1 (low on PA-specific T cells but high on NPspecific T cells) (Suarez-Ramirez et al. 2019). Enriched proinflammatory gene expression status on NP-specific cells and higher expression of Hobit on PA-specific cells also support this idea (Yoshizawa et al. 2018). Thus, the quality and quantity of activation signaling (in combination with TGF- $\beta$ ) may direct developmental bifurcation between $\mathrm{CD}_{103}{ }^{+}$and $\mathrm{CD}_{103}{ }^{-} \mathrm{CD} 8^{+} \mathrm{Trm}$ cells. Such activation events likely take place at the site of infection rather than the initial priming site in the draining $\mathrm{LN}$, as up-regulation of CD103 only occurs upon arrival in the stroma. Given that CD103 expression contributes to synapse formation between $\mathrm{CD}^{+} \mathrm{Trm}$ and target cells (Franciszkiewicz et al. 2013), and accelerates cytotoxic effector functions via a direct outside-in signaling pathway (Le Floc'h et al. 2007, 2011), $\mathrm{CD} 103^{+} \mathrm{CD}^{+}$Trm cells may have superior functionalities compared to their $\mathrm{CD}_{103^{-}}$ counterparts. This raises interesting questions regarding the significance of $\mathrm{CD}_{103^{-}} \mathrm{CD}^{+}$ Trm cells in the stroma.

A recent study reveals that $\mathrm{CD} 103^{+}$, but not $\mathrm{CD}_{103^{-}}, \mathrm{CD}^{+}$Trm cells have a significantly greater reliance on extracellular ATP (eATP)driven signals via its receptor P2RX7, which promotes mitochondrial activity and fusion (Borges da Silva et al. 2018). P2RX7 is selectively expressed on Trm cells (presumably primarily on $\mathrm{CD} 103^{+}$cells) (Stark et al. 2018; Yoshizawa et al. 2018; Borges da Silva et al. 2019), suggesting a regulatory overlap between CD103 and P2RX7 expression. In contrast to its supportive role in Trm cell formation and maintenance, 
excessive P2RX7 signaling in high eATP environments (e.g., damaged tissues) induces selective deletion of Trm cells (Stark et al. 2018; Borges da Silva et al. 2019). Importantly, TCR triggering down-regulates P2RX7 expression, thereby rescuing Trm cells from eATP-induced cell death (Stark et al. 2018), suggesting a requirement for continuous antigen-driven signaling for the long-term maintenance of Trm cells, particularly those maintained in the damaged tissues such as $\mathrm{CD}^{+}{ }^{+}$Trm cells in the lung interstitium (Takamura et al. 2016). This supports our speculation that lower CD103 expression on Trm cells (relative resistance to high eATP-induced cell death) may be attributed to persistent antigen signaling (theoretically low P2RX7 expression).

$\mathrm{CD} 9^{+} \mathrm{CD} 103^{-} \mathrm{CD}^{+}$Trm cells are also present in the stroma of various tissues, such as the skin, gut, FRT, salivary gland, and brain (Wakim et al. 2010; Bergsbaken and Bevan 2015; Smith et al. 2015; Thom et al. 2015; Watanabe et al. 2015; Pattacini et al. 2019). A CD103 ${ }^{-} \mathrm{CD}^{+}$ Trm cell population has also been described in the brain (Wakim et al. 2010). Presumably, the lack of lymphatic drainage in the parenchyma in the brain allows for the establishment of $\mathrm{CD}_{103^{-}}$cells with reduced tissue-retention capacity. $\mathrm{CD}_{103^{+}}$and $\mathrm{CD}_{103}{ }^{-} \mathrm{CD} 8^{+}$Trm cells in the brain also display distinct gene expression profiles (Wakim et al. 2012; Landrith et al. 2017). CD $103^{+}$Trm cells have a highly enriched tissue-retention signature, accelerated expression of activation-related molecules such as PD-1, and superior effector functions as compared to $\mathrm{CD} 103^{-}$Trm cells (Shwetank et al. 2017 ), reflecting the impact of TGF- $\beta$ and local antigen encounters in the development of $\mathrm{CD}_{103}{ }^{+}$Trm cells.

In the case of the small intestine, TGF- $\beta$ is required for the development of $\mathrm{CD} 103^{+} \mathrm{Trm}$ cells, while the inflammatory cytokines IFN- $\alpha$ and IL-12 facilitate the formation of the CD103- Trm cell subset (Bergsbaken and Bevan 2015; Bergsbaken et al. 2017). Localization of these Trm cell subsets also differs. Whereas $\mathrm{CD} 103^{+} \mathrm{CD}^{+}$Trm cells are evenly distributed throughout the stroma, $\mathrm{CD} 103^{-} \mathrm{CD} 8^{+}$Trm cells are maintained in clusters along with $\mathrm{CD} 4^{+}$
$\mathrm{T}$ cells and $\mathrm{CX}_{3} \mathrm{CR}^{+}$APCs (Bergsbaken and Bevan 2015). The proximal positioning with other immune cell populations might compensate for the cells' weakened retention due to the absence of CD103. Taken together, it is clear that distinct environmental cues generate distinct subsets of Trm cells in the stroma. Given the diversity of Trm cell populations in the stroma, it is of interest to investigate the actual contribution and potential division of labor of each Trm cell subset in the recall response.

\section{Stromal CD4 ${ }^{+}$Trm Cell Subpopulations}

Memory $\mathrm{CD}^{+} \mathrm{T}$ cells outnumber memory $\mathrm{CD}^{+} \mathrm{T}$ cells in the stroma of most mucosal and barrier tissues (Sathaliyawala et al. 2013). They include Tem circulating between NLTs and SLOs that rapidly traffic through the stroma (Gebhardt et al. 2011) and Trm cells that are established and maintained at the site of infection (Teijaro et al. 2011; Iijima and Iwasaki 2014; Stary et al. 2015; Romagnoli et al. 2017). As with $\mathrm{CD}^{+} \mathrm{T}$ cells, tissue-specific instructions, including cognate antigen-driven second hits early after initial priming, govern $\mathrm{CD} 4^{+}$Trm cell fate decisions (Fig. 1A). In the mouse models of influenza virus infection and asthma, second hit-driven autocrine IL-2 signaling in combination with IL-15 signaling favors memory commitment in the lung interstitium by inducing prolonged survival (McKinstry et al. 2014; Hondowicz et al. 2016; Strutt et al. 2018). Down-regulation of T-bet is also an essential cell-intrinsic event necessary for the establishment of Trm cells (Dhume et al. 2019). Additional master cytokine signaling probably plays a role in dictating the heterogeneity of wellknown $\mathrm{CD}^{+}{ }^{+} \mathrm{T}$-cell subsets.

Emerging data suggests that $\mathrm{CD} 4^{+}$Trm cells can also be divided into two subpopulations based on their expression of CD103 (Turner et al. 2014; Collins et al. 2016; Romagnoli et al. 2017; Wilk et al. 2017). Although the actual role of CD103 in their localization within the stroma is largely unknown, canonical Trm cell transcriptional signatures and superior polyfunctionality (Th1 cytokines) has been reported for $\mathrm{CD}_{103}{ }^{+} \mathrm{CD} 4^{+}$Trm cells (Watanabe et al. 2015; 


\section{S. Takamura}

Oja et al. 2018). In contrast, in a mouse model of chronic antigen exposure, antigen-specific $\mathrm{CD}_{103^{-}} \mathrm{CD}^{+}$Trm cells generated in the lung display a greater ability to secrete proinflammatory cytokines than their $\mathrm{CD}_{103^{+}}$counterparts, and cause fibrotic responses through elevated production of Th2 cytokines, including IL-4, IL-5, and IL-13 (Ichikawa et al. 2019). IL-33 signaling accelerates the generation of the pathogenic subpopulation of resident $\mathrm{CD} 103^{-} \mathrm{CD} 4^{+}$ $\mathrm{T}$ cells, while TGF- $\beta$ potentially promotes the establishment of $\mathrm{CD} 103^{+} \mathrm{FoxP}^{+} \mathrm{CD} 4^{+} \mathrm{T}$ cells with regulatory capacities (Morimoto et al. 2018; Ichikawa et al. 2019). A better understanding of the biology of these Trm cell subpopulations may lead to the development of new immunomodulatory therapeutics.

Unlike $\mathrm{CD}^{+}$Trm cells, which are usually distributed throughout the stroma and without forming lymphoid structures, $\mathrm{CD} 4^{+}$Trm cells in the stromal tissues preferentially localize in lymphoid aggregates, including ectopic lymphoid structures such as inducible bronchus-associated lymphoid tissue (iBALT) (Clark et al. 2006; Iijima and Iwasaki 2014; Turner et al. 2014; Collins et al. 2016). This distribution reflects their tropism for sites that promote interactions with APCs. Interestingly, stromal CD $4^{+}$Trm cells established at sites distal to the infection site mostly lack the expression of CD103 and fail to form clusters (Beura et al. 2019), suggesting a primary role for a second hit with cognate antigen. One exception is the dermis in the skin, where $\mathrm{CD} 9^{+} \mathrm{CD} 103^{+} \mathrm{CD}^{+} \mathrm{T}$ cells could be established and form clusters in the perifollicular area even in the absence of infection (Collins et al. 2016). This suggests a role for local tissue-resident macrophages in attracting $\mathrm{CD} 4^{+}$ $\mathrm{T}$ cells under steady-state conditions. Of note, long-period parabiosis experiments (12-16 weeks) using naive animals has revealed the slow emergence of partner (circulation)-derived $\mathrm{CD} 9^{+} \mathrm{CD} 103^{+} \mathrm{CD} 4^{+} \mathrm{T}$ cells, which coincides with the loss of host $\mathrm{CD} 69^{+} \mathrm{CD} 103^{+} \mathrm{CD} 4^{+} \mathrm{T}$ cells in the dermis (Collins et al. 2016). This suggests that dermal CD $4^{+}$Trm cells leave tissues in the same manner as Tem cells (theoretically after down-regulation of CD69). In fact, a recent study identified the presence of skin-tropic
$\mathrm{CD} 9^{-} / \mathrm{CD} 103^{+}$memory $\mathrm{CD} 4^{+} \mathrm{T}$ cells having a Trm cell gene signature in the circulation and proposed a model of skin $\mathrm{CD}^{+}{ }^{+}$Trm cell recirculation (ex-Trm cell model). Because ectopic lymphoid structures usually consist of high endothelial venules (HEVs) and efferent lymph vessels (Randall and Mebius 2014), this slow rate of recirculation may be a feature of $\mathrm{CD}^{+}$ Trm cells. This ex-Trm cell model does not contradict a previously proposed model of $\mathrm{CD}^{+}$ Trm cell tissue residency (Glennie et al. 2015; Snyder et al. 2019), because the stable expression of CD69, especially at the site of infection/ immunization, induces prolonged retention (Turner et al. 2014; Shinoda et al. 2016). Taken together, the data suggest that activation signals likely dictate the durability of $\mathrm{CD}^{+}{ }^{+}$Trm cells, and, thus, the route of infection/immunization is a critical factor (Fig. 1).

\section{CONCLUDING REMARKS}

The discovery of Trm cells has substantially advanced our understanding of regional protective immunity. However, further progress has been complicated by the lack of precise definitions of Trm cell subsets. For example, categorizing Trm cells exclusively by surface markers potentially fails to identify noncanonical Trm cell subpopulations (e.g., the CD103- Trm cell subpopulations). Furthermore, inattention to a subpopulation's antigenic experience and specific anatomical location or distribution in a tissue might reduce our ability to distinguish distinct Trm cell subpopulations (e.g., lung $\mathrm{CD}_{103^{+}}$ Trm cells generated by pulmonary or systemic infections). Hence, it is important to remember that Trm cells are defined fundamentally by their tissue residency, and the role of local instructive stimuli have to be considered in the differential fate commitment of Trm cells.

In addition to the role of Trm cells as a firstline defense against infection, Trm cells also drive autoimmunity, allergy, and inflammatory disease (Masopust and Soerens 2019). Furthermore, $\mathrm{CD}^{+} \mathrm{T}$ cells with Trm cell signatures are being identified among tumor-infiltrating lymphocytes (TILs), and their presence is often associated with a favorable prognosis (Amsen et al. 
2018). On the other hand, because immune checkpoint molecules, such as PD-1, are known to be frequently expressed on Trm cells, their participation in the development of immunerelated adverse events is suspected during immune checkpoint blockade therapy. Thus, identification of the specific Trm cell subsets responsible for protective immunity as well as progressive pathogenesis has significant implications for therapeutic intervention. In light of this, a unifying classification of tissue memory is urgently needed. As technologies advance for the study of these cells, the establishment of fundamental Trm cell subset definitions will be essential for understanding the complexities of Trm cell biology and for the development of treatments to improve human health.

\section{ACKNOWLEDGMENTS}

We thank David L. Woodland for assistance in editing the manuscript. This work was supported by grants from The Naito Foundation, SENSHIN Medical Research Foundation, Takeda Science Foundation, Mochida Memorial Foundation for Medical and Pharmaceutical Research, and Kindai University 21st Century Joint Research Enhancement Grant.

\section{REFERENCES}

Abboud G, Desai P, Dastmalchi F, Stanfield J, Tahiliani V, Hutchinson TE, Salek-Ardakani S. 2016. Tissue-specific programming of memory CD8 T cell subsets impacts protection against lethal respiratory virus infection. $J$ Exp Med 213: 2897-2911. doi:10.1084/jem.20160167

Amsen D, van Gisbergen K, Hombrink P, van Lier RAW. 2018. Tissue-resident memory $T$ cells at the center of immunity to solid tumors. Nat Immunol 19: 538-546. doi:10.1038/s41590-018-0114-2

Anderson KG, Sung H, Skon CN, Lefrancois L, Deisinger A, Vezys V, Masopust D. 2012. Cutting edge: intravascular staining redefines lung CD8 $\mathrm{T}$ cell responses. J Immunol 189: 2702-2706. doi:10.4049/jimmunol.1201682

Ariotti S, Beltman JB, Chodaczek G, Hoekstra ME, van Beek AE, Gomez-Eerland R, Ritsma L, van Rheenen J, Maree AF, Zal T, et al. 2012. Tissue-resident memory $\mathrm{CD}^{+} \mathrm{T}$ cells continuously patrol skin epithelia to quickly recognize local antigen. Proc Natl Acad Sci 109: 19739-19744. doi:10.1073/pnas.1208927109

Ariotti S, Hogenbirk MA, Dijkgraaf FE, Visser LL, Hoekstra ME, Song JY, Jacobs H, Haanen JB, Schumacher TN 2014. T cell memory. Skin-resident memory $\mathrm{CD}^{+} \mathrm{T}$ cells trigger a state of tissue-wide pathogen alert. Science 346: 101-105. doi:10.1126/science.1254803

Bachem A, Makhlouf C, Binger KJ, de Souza DP, Tull D, Hochheiser K, Whitney PG, Fernandez-Ruiz D, Dähling S, Kastenmüller W, et al. 2019. Microbiota-derived shortchain fatty acids promote the memory potential of antigen-activated $\mathrm{CD}^{+} \mathrm{T}$ cells. Immunity 51: 285-297.e5. doi:10.1016/j.immuni.2019.06.002

Behr FM, Chuwonpad A, Stark R, van Gisbergen K. 2018. Armed and ready: transcriptional regulation of tissueresident memory CD8 T cells. Front Immunol 9: 1770. doi:10.3389/fimmu.2018.01770

Behr FM, Kragten NAM, Wesselink TH, Nota B, van Lier RAW, Amsen D, Stark R, Hombrink P, van Gisbergen K. 2019. Blimp-1 rather than Hobit drives the formation of tissue-resident memory $\mathrm{CD}^{+}{ }^{+} \mathrm{T}$ cells in the lungs. Front Immunol 10: 400. doi:10.3389/fimmu.2019.00400

Bergsbaken T, Bevan MJ. 2015. Proinflammatory microenvironments within the intestine regulate the differentiation of tissue-resident $\mathrm{CD} 8^{+} \mathrm{T}$ cells responding to infection. Nat Immunol 16: 406-414. doi:10.1038/ni.3108

Bergsbaken T, Bevan MJ, Fink PJ. 2017. Local inflammatory cues regulate differentiation and persistence of $\mathrm{CD}^{+}$tissue-resident memory T cells. Cell Rep 19: 114-124. doi:10 .1016/j.celrep.2017.03.031

Beura LK, Anderson KG, Schenkel JM, Locquiao JJ, Fraser KA, Vezys V, Pepper M, Masopust D. 2015. Lymphocytic choriomeningitis virus persistence promotes effector-like memory differentiation and enhances mucosal T cell distribution. J Leukoc Biol 97: 217-225. doi:10.1189/jlb .1HI0314-154R

Beura LK, Hamilton SE, Bi K, Schenkel JM, Odumade OA, Casey KA, Thompson EA, Fraser KA, Rosato PC, FilaliMouhim A, et al. 2016. Normalizing the environment recapitulates adult human immune traits in laboratory mice. Nature 532: 512-516. doi:10.1038/nature17655

Beura LK, Fares-Frederickson NJ, Steinert EM, Scott MC, Thompson EA, Fraser KA, Schenkel JM, Vezys V, Masopust D. 2019. CD4 ${ }^{+}$resident memory $\mathrm{T}$ cells dominate immunosurveillance and orchestrate local recall responses. J Exp Med 216: 1214-1229. doi:10.1084/jem .20181365

Booth JS, Patil SA, Goldberg E, Barnes RS, Greenwald BD, Sztein MB. 2019. Attenuated oral typhoid vaccine Ty21a elicits lamina propria and intra-epithelial lymphocyte tissue-resident effector memory CD8 $\mathrm{T}$ responses in the human terminal ileum. Front Immunol 10: 424. doi:10 .3389/fimmu.2019.00424

Borges da Silva H, Beura LK, Wang H, Hanse EA, Gore R, Scott MC, Walsh DA, Block KE, Fonseca R, Yan Y, et al. 2018. The purinergic receptor P2RX7 directs metabolic fitness of long-lived memory $\mathrm{CD}^{+} \mathrm{T}$ cells. Nature 559: 264-268. doi:10.1038/s41586-018-0282-0

Borges da Silva H, Wang H, Qian LJ, Hogquist KA, Jameson SC. 2019. ARTC2.2/P2RX7 signaling during cell isolation distorts function and quantification of tissue-resident $\mathrm{CD}^{+} \mathrm{T}$ cell and invariant NKT subsets. J Immunol 202: 2153-2163. doi:10.4049/jimmunol.1801613

Caldeira-Dantas S, Furmanak T, Smith C, Quinn M, Teos LY, Ertel A, Kurup D, Tandon M, Alevizos I, Snyder CM. 2018. The chemokine receptor CXCR3 promotes CD8 ${ }^{+}$ $\mathrm{T}$ cell accumulation in uninfected salivary glands but is 


\section{S. Takamura}

not necessary after murine cytomegalovirus infection. J Immunol 200: 1133-1145. doi:10.4049/jimmunol .1701272

Casey KA, Fraser KA, Schenkel JM, Moran A, Abt MC, Beura LK, Lucas PJ, Artis D, Wherry EJ, Hogquist K, et al. 2012. Antigen-independent differentiation and maintenance of effector-like resident memory $\mathrm{T}$ cells in tissues. J Immunol 188: 4866-4875. doi:10.4049/jimmunol .1200402

Cheuk S, Schlums H, Gallais Sérézal I, Martini E, Chiang SC, Marquardt N, Gibbs A, Detlofsson E, Introini A, Forkel $\mathrm{M}$, et al. 2017. CD49a expression defines tissue-resident $\mathrm{CD} 8^{+} \mathrm{T}$ cells poised for cytotoxic function in human skin. Immunity 46: 287-300. doi:10.1016/j.immuni.2017.01 .009

Clark RA, Chong B, Mirchandani N, Brinster NK, Yamanaka K, Dowgiert RK, Kupper TS. 2006. The vast majority of CLA ${ }^{+} \mathrm{T}$ cells are resident in normal skin. J Immuno 176: 4431-4439. doi:10.4049/jimmunol.176.7.4431

Collins N, Jiang X, Zaid A, Macleod BL, Li J, Park CO, Haque A, Bedoui S, Heath WR, Mueller SN, et al. 2016. Skin $\mathrm{CD} 4^{+}$memory $\mathrm{T}$ cells exhibit combined cluster-mediated retention and equilibration with the circulation. Nat Commun 7: 11514. doi:10.1038/ncomms11514

Desai P, Tahiliani V, Stanfield J, Abboud G, Salek-Ardakani S. 2018. Inflammatory monocytes contribute to the persistence of CXCR $3^{\text {hi }}$ CX3CR $1^{\text {lo }}$ circulating and lung-resident memory $\mathrm{CD}^{+} \mathrm{T}$ cells following respiratory virus infection. Immunol Cell Biol 96: 370-378. doi:10.1111/ imcb. 12006

Dhume K, Finn CM, Strutt TM, Sell S, McKinstry KK. 2019. T-bet optimizes CD4 T-cell responses against influenza through CXCR3-dependent lung trafficking but not functional programming. Mucosal Immunol 12: 1220-1230. doi:10.1038/s41385-019-0183-Z

Dijkgraaf FE, Matos TR, Hoogenboezem M, Toebes M, Vredevoogd DW, Mertz M, van den Broek B, Song JY, Teunissen MBM, Luiten RM, et al. 2019. Tissue patrol by resident memory CD8 $8^{+} \mathrm{T}$ cells in human skin. Nat Immunol 20: 756-764. doi:10.1038/s41590-019-0404-3

Ely KH, Cookenham T, Roberts AD, Woodland DL. 2006. Memory $\mathrm{T}$ cell populations in the lung airways are maintained by continual recruitment. J Immunol 176: 537 543. doi:10.4049/jimmunol.176.1.537

Fahrer AM, Konigshofer Y, Kerr EM, Ghandour G, Mack DH, Davis MM, Chien YH. 2001. Attributes of $\gamma \delta$ intraepithelial lymphocytes as suggested by their transcriptional profile. Proc Natl Acad Sci 98: 10261-10266. doi:10.1073/pnas.171320798

Fernandez-Ruiz D, Ng WY, Holz LE, Ma JZ, Zaid A, Wong YC, Lau LS, Mollard V, Cozijnsen A, Collins N, et al. 2016. Liver-resident memory $\mathrm{CD} 8^{+} \mathrm{T}$ cells form a front-line defense against malaria liver-stage infection. Immunity 45: 889-902. doi:10.1016/j.immuni.2016.08.011

Franciszkiewicz K, Le Floc'h A, Boutet M, Vergnon I, Schmitt A, Mami-Chouaib F. 2013. CD103 or LFA-1 engagement at the immune synapse between cytotoxic $\mathrm{T}$ cells and tumor cells promotes maturation and regulates T-cell effector functions. Cancer Res 73: 617-628. doi:10 .1158/0008-5472.CAN-12-2569

Frost EL, Kersh AE, Evavold BD, Lukacher AE. 2015. Cutting edge: resident memory CD8 $\mathrm{T}$ cells express high-af- finity TCRs. J Immunol 195: 3520-3524. doi:10.4049/jim munol.1501521

Gebhardt T, Wakim LM, Eidsmo L, Reading PC, Heath WR, Carbone FR. 2009. Memory T cells in nonlymphoid tissue that provide enhanced local immunity during infection with herpes simplex virus. Nat Immunol 10: 524-530. doi:10.1038/ni.1718

Gebhardt T, Whitney PG, Zaid A, Mackay LK, Brooks AG, Heath WR, Carbone FR, Mueller SN. 2011. Different patterns of peripheral migration by memory $\mathrm{CD} 4^{+}$and $\mathrm{CD} 8^{+}$ T cells. Nature 477: 216-219. doi:10.1038/nature10339

Gilchuk P, Hill Timothy M, Guy C, McMaster Sean R, Boyd Kelli L, Rabacal Whitney A, Lu P, Shyr Y, Kohlmeier Jacob E, Sebzda E, et al. 2016. A distinct lung-interstitium-resident memory $\mathrm{CD}^{+} \mathrm{T}$ cell subset confers enhanced protection to lower respiratory tract infection. Cell Rep 16: 1800-1809. doi:10.1016/j.celrep.2016.07.037

Glennie ND, Yeramilli VA, Beiting DP, Volk SW, Weaver CT, Scott P. 2015. Skin-resident memory CD4 ${ }^{+} \mathrm{T}$ cells enhance protection against Leishmania major infection. J Exp Med 212: 1405-1414. doi:10.1084/jem.20142101

Hayward SL, Scharer CD, Cartwright EK, Takamura S, Tiger Li ZR, Boss JM, Kohlmeier JE. 2020. Environmental cues regulate epigenetic reprogramming of airway-resident memory $\mathrm{CD}^{+} \mathrm{T}$ cells. Nat Immunol 21: 309-320. doi:10.1038/s41590-019-0584-x

Hirai T, Zenke Y, Yang Y, Bartholin L, Beura LK, Masopust D, Kaplan DH. 2019. Keratinocyte-mediated activation of the cytokine TGF- $\beta$ maintains skin recirculating memory $\mathrm{CD}^{+} \mathrm{T}$ cells. Immunity 50: 1249-1261.e5. doi:10.1016/j .immuni.2019.03.002

Hogan RJ, Usherwood EJ, Zhong W, Roberts AA, Dutton RW, Harmsen AG, Woodland DL. 2001. Activated antigen-specific $\mathrm{CD}^{+} \mathrm{T}$ cells persist in the lungs following recovery from respiratory virus infections. J Immunol 166: 1813-1822. doi:10.4049/jimmunol.166.3.1813

Holz LE, Prier JE, Freestone D, Steiner TM, English K, Johnson DN, Mollard V, Cozijnsen A, Davey GM, Godfrey DI, et al. 2018. CD8 ${ }^{+} \mathrm{T}$ cell activation leads to constitutive formation of liver tissue-resident memory $\mathrm{T}$ cells that seed a large and flexible niche in the liver. Cell Rep 25: 68-79.e4. doi:10.1016/j.celrep.2018.08.094

Hondowicz BD, An D, Schenkel JM, Kim KS, Steach HR, Krishnamurty AT, Keitany GJ, Garza EN, Fraser KA, Moon JJ, et al. 2016. Interleukin-2-dependent allergenspecific tissue-resident memory cells drive asthma. Immunity 44: 155-166. doi:10.1016/j.immuni.2015.11.004

Hu Y, Lee YT, Kaech SM, Garvy B, Cauley LS. 2015. Smad4 promotes differentiation of effector and circulating memory $\mathrm{CD} 8 \mathrm{~T}$ cells but is dispensable for tissue-resident memory CD8 T cells. J Immunol 194: 2407-2414. doi:10.4049/jimmunol.1402369

Ichikawa T, Hirahara K, Kokubo K, Kiuchi M, Aoki A, Morimoto Y, Kumagai J, Onodera A, Mato N, Tumes DJ, et al. 2019. CD $103^{\text {hi }}$ Treg cells constrain lung fibrosis induced by $\mathrm{CD} 103^{\mathrm{lo}}$ tissue-resident pathogenic CD4 T cells. Nat Immunol 20: 1469-1480. doi:10.1038/s41590-0190494-y

Iijima N, Iwasaki A. 2014. T cell memory. A local macrophage chemokine network sustains protective tissue-resident memory CD4 T cells. Science 346: 93-98. doi:10 $.1126 /$ science. 1257530 
Jiang X, Clark RA, Liu L, Wagers AJ, Fuhlbrigge RC, Kupper TS. 2012. Skin infection generates non-migratory memory $\mathrm{CD}^{+} \mathrm{T}_{\mathrm{RM}}$ cells providing global skin immunity. $\mathrm{Na}$ ture 483: 227-231. doi:10.1038/nature10851

Kadow S, Jux B, Zahner SP, Wingerath B, Chmill S, Clausen BE, Hengstler J, Esser C. 2011. Aryl hydrocarbon receptor is critical for homeostasis of invariant $\gamma \delta \mathrm{T}$ cells in the murine epidermis. J Immunol 187: 3104-3110. doi:10 .4049/jimmunol.1100912

Kallies A, Xin A, Belz GT, Nutt SL. 2009. Blimp-1 transcription factor is required for the differentiation of effector $\mathrm{CD}^{+} \mathrm{T}$ cells and memory responses. Immunity $31: 283$ 295. doi:10.1016/j.immuni.2009.06.021

Kelly A, Gunaltay S, McEntee CP, Shuttleworth EE, Smedley C, Houston SA, Fenton TM, Levison S, Mann ER, Travis MA. 2018. Human monocytes and macrophages regulate immune tolerance via integrin $\alpha \beta 8$-mediated TGF $\beta$ activation. J Exp Med 215: 2725-2736. doi:10.1084/jem .20171491

Khan TN, Mooster JL, Kilgore AM, Osborn JF, Nolz JC. 2016. Local antigen in nonlymphoid tissue promotes resident memory $\mathrm{CD}^{+} \mathrm{T}$ cell formation during viral infection. J Exp Med 213: 951-966. doi:10.1084/jem.20151855

Klonowski KD, Williams KJ, Marzo AL, Blair DA, Lingenheld EG, Lefrançois L. 2004. Dynamics of blood-borne CD8 memory $\mathrm{T}$ cell migration in vivo. Immunity 20: 551 562. doi:10.1016/S1074-7613(04)00103-7

Kohlmeier JE, Miller SC, Woodland DL. 2007. Cutting edge: antigen is not required for the activation and maintenance of virus-specific memory $\mathrm{CD}^{+} \mathrm{T}$ cells in the lung airways. J Immunol 178: 4721-4725. doi:10.4049/ jimmunol.178.8.4721

Konjar S, Frising UC, Ferreira C, Hinterleitner R, Mayassi T, Zhang Q, Blankenhaus B, Haberman N, Loo Y, Guedes J, et al. 2018. Mitochondria maintain controlled activation state of epithelial-resident T lymphocytes. Sci Immunol 3: eaan2543. doi:10.1126/sciimmunol.aan2543

Kumar BV, Ma W, Miron M, Granot T, Guyer RS, Carpenter DJ, Senda T, Sun X, Ho SH, Lerner H, et al. 2017. Human tissue-resident memory $\mathrm{T}$ cells are defined by core transcriptional and functional signatures in lymphoid and mucosal sites. Cell Rep 20: 2921-2934. doi:10.1016/j .celrep.2017.08.078

Kunkel EJ, Campbell JJ, Haraldsen G, Pan J, Boisvert J, Roberts AI, Ebert EC, Vierra MA, Goodman SB, Genovese MC, et al. 2000. Lymphocyte CC chemokine receptor 9 and epithelial thymus-expressed chemokine (TECK) expression distinguish the small intestinal immune compartment: epithelial expression of tissue-specific chemokines as an organizing principle in regional immunity. $J$ Exp Med 192: 761-768. doi:10.1084/jem.192.5.761

Landrith TA, Sureshchandra S, Rivera A, Jang JC, Rais M, Nair MG, Messaoudi I, Wilson EH. 2017. CD103 ${ }^{+}$CD8 T cells in the toxoplasma-infected brain exhibit a tissueresident memory transcriptional profile. Front Immunol 8: 335. doi:10.3389/fimmu.2017.00335

Lauron EJ, Yang L, Harvey IB, Sojka DK, Williams GD, Paley MA, Bern MD, Park E, Victorino F, Boon ACM, et al. 2019. Viral MHCI inhibition evades tissue-resident memory T cell formation and responses. J Exp Med 216: 117132. doi:10.1084/jem.20181077
Lee YT, Suarez-Ramirez JE, Wu T, Redman JM, Bouchard K, Hadley GA, Cauley LS. 2011. Environmental and antigen receptor-derived signals support sustained surveillance of the lungs by pathogen-specific cytotoxic T lymphocytes. J Virol 85: 4085-4094. doi:10.1128/JVI.02493-10

Le Floc'h A, Jalil A, Vergnon I, Le Maux Chansac B, Lazar V, Bismuth G, Chouaib S, Mami-Chouaib F. 2007. $\alpha E \beta 7$ integrin interaction with $\mathrm{E}$-cadherin promotes antitumor CTL activity by triggering lytic granule polarization and exocytosis. J Exp Med 204: 559-570. doi:10.1084/jem .20061524

Le Floc'h A, Jalil A, Franciszkiewicz K, Validire P, Vergnon I, Mami-Chouaib F. 2011. Minimal engagement of CD103 on cytotoxic T lymphocytes with an E-cadherin-Fc molecule triggers lytic granule polarization via a phospholipase C $\gamma$-dependent pathway. Cancer Res 71: 328-338. doi:10.1158/0008-5472.CAN-10-2457

Mackay LK, Stock AT, Ma JZ, Jones CM, Kent SJ, Mueller SN, Heath WR, Carbone FR, Gebhardt T. 2012. Longlived epithelial immunity by tissue-resident memory $\mathrm{T}$ $\left(\mathrm{T}_{\mathrm{RM}}\right)$ cells in the absence of persisting local antigen presentation. Proc Natl Acad Sci 109: 7037-7042. doi:10 $.1073 /$ pnas.1202288109

Mackay LK, Rahimpour A, Ma JZ, Collins N, Stock AT, Hafon ML, Vega-Ramos J, Lauzurica P, Mueller SN, Stefanovic T, et al. 2013. The developmental pathway for $\mathrm{CD} 103^{+} \mathrm{CD}^{+}$tissue-resident memory $\mathrm{T}$ cells of skin. Nat Immunol 14: 1294-1301. doi:10.1038/ni.2744

Mackay LK, Braun A, Macleod BL, Collins N, Tebartz C, Bedoui S, Carbone FR, Gebhardt T. 2015a. Cutting edge: CD69 interference with sphingosine-1-phosphate receptor function regulates peripheral $\mathrm{T}$ cell retention. $J$ Immunol 194: 2059-2063. doi:10.4049/jimmunol.14 02256

Mackay LK, Wynne-Jones E, Freestone D, Pellicci DG, Mielke LA, Newman DM, Braun A, Masson F, Kallies A, Belz GT, et al. 2015b. T-box transcription factors combine with the cytokines TGF- $\beta$ and IL-15 to control tissue-resident memory $\mathrm{T}$ cell fate. Immunity 43: 11011111. doi:10.1016/j.immuni.2015.11.008

Mackay LK, Minnich M, Kragten NA, Liao Y, Nota B, Seillet C, Zaid A, Man K, Preston S, Freestone D, et al. 2016. Hobit and Blimp1 instruct a universal transcriptional program of tissue residency in lymphocytes. Science 352: 459-463. doi:10.1126/science.aad2035

Masopust D, Soerens AG. 2019. Tissue-resident T cells and other resident leukocytes. Annu Rev Immunol 37: 521546. doi:10.1146/annurev-immunol-042617-053214

Masopust D, Vezys V, Marzo AL, Lefrançois L. 2001. Preferential localization of effector memory cells in nonlymphoid tissue. Science 291: 2413-2417. doi:10.1126/sci ence. 1058867

Masopust D, Choo D, Vezys V, Wherry EJ, Duraiswamy J, Akondy R, Wang J, Casey KA, Barber DL, Kawamura KS, et al. 2010. Dynamic T cell migration program provides resident memory within intestinal epithelium. J Exp Med 207: 553-564. doi:10.1084/jem.20090858

McCully ML, Ladell K, Andrews R, Jones RE, Miners KL, Roger L, Baird DM, Cameron MJ, Jessop ZM, Whitaker IS, et al. 2018. CCR8 expression defines tissue-resident memory T cells in human skin. J Immunol 200: 16391650. 


\section{S. Takamura}

McGill J, Legge KL. 2009. Cutting edge: contribution of lung-resident $\mathrm{T}$ cell proliferation to the overall magnitude of the antigen-specific CD8 $\mathrm{T}$ cell response in the lungs following murine influenza virus infection. J Immunol 183: 4177-4181. doi:10.4049/jimmunol.0901109

McGill J, Van Rooijen N, Legge KL. 2008. Protective influenza-specific CD8 $\mathrm{T}$ cell responses require interactions with dendritic cells in the lungs. J Exp Med 205: 16351646. doi:10.1084/jem.20080314

McGill J, Van Rooijen N, Legge KL. 2010. IL-15 trans-presentation by pulmonary dendritic cells promotes effector CD8 T cell survival during influenza virus infection. J Exp Med 207: 521-534. doi:10.1084/jem.20091711

McKinstry KK, Strutt TM, Bautista B, Zhang W, Kuang Y, Cooper AM, Swain SL. 2014. Effector CD4 T-cell transition to memory requires late cognate interactions that induce autocrine IL-2. Nat Commun 5: 5377. doi:10 $.1038 /$ ncomms6377

McMaster SR, Wilson JJ, Wang H, Kohlmeier JE. 2015. Airway-resident memory CD8 T cells provide antigenspecific protection against respiratory virus challenge through rapid IFN- $\gamma$ production. J Immunol 195: 203209. doi:10.4049/jimmunol.1402975

McMaster SR, Wein AN, Dunbar PR, Hayward SL, Cartwright EK, Denning TL, Kohlmeier JE. 2018. Pulmonary antigen encounter regulates the establishment of tissueresident CD8 memory $\mathrm{T}$ cells in the lung airways and parenchyma. Mucosal Immunol 11: 1071-1078. doi:10 .1038/s41385-018-0003-x

Milner JJ, Goldrath AW. 2018. Transcriptional programming of tissue-resident memory $\mathrm{CD}^{+} \mathrm{T}$ cells. Curr Opin Immunol 51: 162-169. doi:10.1016/j.coi.2018.03 .017

Milner JJ, Toma C, Yu B, Zhang K, Omilusik K, Phan AT, Wang D, Getzler AJ, Nguyen T, Crotty S, et al. 2017. Runx3 programs $\mathrm{CD}^{+} \mathrm{T}$ cell residency in non-lymphoid tissues and tumours. Nature 552: 253-257. doi:10.1038/ nature24993

Moalli F, Ficht X, Germann P, Vladymyrov M, Stolp B, de Vries I, Lyck R, Balmer J, Fiocchi A, Kreutzfeldt M, et al. 2018. The Rho regulator Myosin IXb enables nonlymphoid tissue seeding of protective $\mathrm{CD}^{+} \mathrm{T}$ cells. J Exp Med 215: 1869-1890. doi:10.1084/jem.20170896

Mohammed J, Beura LK, Bobr A, Astry B, Chicoine B, Kashem SW, Welty NE, Igyártó BZ, Wijeyesinghe S, Thompson EA, et al. 2016. Stromal cells control the epithelial residence of DCs and memory $\mathrm{T}$ cells by regulated activation of TGF- $\beta$. Nat Immunol 17: 414-421. doi:10.1038/ ni.3396

Morales J, Homey B, Vicari AP, Hudak S, Oldham E, Hedrick J, Orozco R, Copeland NG, Jenkins NA, McEvoy LM, et al. 1999. CTACK, a skin-associated chemokine that preferentially attracts skin-homing memory $\mathrm{T}$ cells. Proc Natl Acad Sci 96: 14470-14475. doi:10.1073/pnas.96 .25 .14470

Morimoto Y, Hirahara K, Kiuchi M, Wada T, Ichikawa T, Kanno T, Okano M, Kokubo K, Onodera A, Sakurai D, et al. 2018. Amphiregulin-producing pathogenic memory T helper 2 cells instruct eosinophils to secrete osteopontin and facilitate airway fibrosis. Immunity 49: 134-150.e6. doi:10.1016/j.immuni.2018.04.023
Muschaweckh A, Buchholz VR, Fellenzer A, Hessel C, König PA, Tao S, Tao R, Heikenwälder M, Busch DH, Korn T, et al. 2016. Antigen-dependent competition shapes the local repertoire of tissue-resident memory $\mathrm{CD}^{+} \mathrm{T}$ cells. J Exp Med 213: 3075-3086. doi:10.1084/jem.20160888

Nakanishi Y, Lu B, Gerard C, Iwasaki A. 2009. CD8 ${ }^{+}$ $\mathrm{T}$ lymphocyte mobilization to virus-infected tissue requires $\mathrm{CD}^{+}$T-cell help. Nature 462: 510-513. doi:10 $.1038 /$ nature08511

Oja AE, Piet B, Helbig C, Stark R, van der Zwan D, Blaauwgeers $\mathrm{H}$, Remmerswaal EBM, Amsen D, Jonkers RE, Moerland PD, et al. 2018. Trigger-happy resident memory $\mathrm{CD}^{+} \mathrm{T}$ cells inhabit the human lungs. Mucosal Immunol 11: 654-667. doi:10.1038/mi.2017.94

Pan Y, Tian T, Park CO, Lofftus SY, Mei S, Liu X, Luo C, O'Malley JT, Gehad A, Teague JE, et al. 2017. Survival of tissue-resident memory $\mathrm{T}$ cells requires exogenous lipid uptake and metabolism. Nature 543: 252-256. doi:10 $.1038 /$ nature21379

Pattacini L, Woodward Davis A, Czartoski J, Mair F, Presnell S, Hughes SM, Hyrien O, Lentz GM, Kirby AC, Fialkow MF, et al. 2019. A pro-inflammatory $\mathrm{CD}^{+}{ }^{+} \mathrm{T}$-cell subset patrols the cervicovaginal tract. Mucosal Immunol 12: 1118-1129. doi:10.1038/s41385-019-0186-9

Pauls K, Schön M, Kubitza RC, Homey B, Wiesenborn A, Lehmann P, Ruzicka T, Parker CM, Schön MP. 2001. Role of integrin $\alpha_{E}(C D 103) \beta_{7}$ for tissue-specific epidermal localization of $\mathrm{CD}^{+} \mathrm{T}$ lymphocytes. J Invest Dermatol 117: 569-575. doi:10.1046/j.0022-202x.2001.01481.x

Pizzolla A, Wang Z, Groom JR, Kedzierska K, Brooks AG, Reading PC, Wakim LM. 2017. Nasal-associated lymphoid tissues (NALTs) support the recall but not priming of influenza virus-specific cytotoxic T cells. Proc Natl Acad Sci 114: 5225-5230. doi:10.1073/pnas.1620194114

Randall TD, Mebius RE. 2014. The development and function of mucosal lymphoid tissues: a balancing act with micro-organisms. Mucosal Immunol 7: 455-466. doi:10 $.1038 / \mathrm{mi} .2014 .11$

Ray SJ, Franki SN, Pierce RH, Dimitrova S, Koteliansky V, Sprague AG, Doherty PC, de Fougerolles AR, Topham DJ. 2004. The collagen binding $\alpha 1 \beta 1$ integrin VLA-1 regulates CD8 T cell-mediated immune protection against heterologous influenza infection. Immunity 20: 167179. doi:10.1016/S1074-7613(04)00021-4

Reinhardt RL, Khoruts A, Merica R, Zell T, Jenkins MK. 2001. Visualizing the generation of memory CD4 T cells in the whole body. Nature 410: 101-105. doi:10.1038/ 35065111

Romagnoli PA, Fu HH, Qiu Z, Khairallah C, Pham QM, Puddington L, Khanna KM, Lefrançois L, Sheridan BS. 2017. Differentiation of distinct long-lived memory CD4 $\mathrm{T}$ cells in intestinal tissues after oral Listeria monocytogenes infection. Mucosal Immunol 10: 520-530. doi:10 $.1038 / \mathrm{mi} .2016 .66$

Rutishauser RL, Martins GA, Kalachikov S, Chandele A, Parish IA, Meffre E, Jacob J, Calame K, Kaech SM. 2009. Transcriptional repressor Blimp-1 promotes $\mathrm{CD}^{+} \mathrm{T}$ cell terminal differentiation and represses the acquisition of central memory $\mathrm{T}$ cell properties. Immunity 31: 296-308. doi:10.1016/j.immuni.2009.05.014

Sallusto F, Lenig D, Förster R, Lipp M, Lanzavecchia A. 1999. Two subsets of memory $\mathrm{T}$ lymphocytes with distinct 
homing potentials and effector functions. Nature 401: 708-712. doi: $10.1038 / 44385$

Sathaliyawala T, Kubota M, Yudanin N, Turner D, Camp P, Thome JJ, Bickham KL, Lerner H, Goldstein M, Sykes M, et al. 2013. Distribution and compartmentalization of human circulating and tissue-resident memory $\mathrm{T}$ cell subsets. Immunity 38: 187-197. doi:10.1016/j.immuni .2012.09.020

Schenkel JM, Fraser KA, Vezys V, Masopust D. 2013. Sensing and alarm function of resident memory $\mathrm{CD} 8^{+} \mathrm{T}$ cells. Nat Immunol 14: 509-513. doi:10.1038/ni.2568

Schenkel JM, Fraser KA, Beura LK, Pauken KE, Vezys V, Masopust D. 2014. T cell memory. Resident memory CD8 T cells trigger protective innate and adaptive immune responses. Science 346: 98-101. doi:10.1126/sci ence. 1254536

Schenkel JM, Fraser KA, Casey KA, Beura LK, Pauken KE, Vezys V, Masopust D. 2016. IL-15-independent maintenance of tissue-resident and boosted effector memory CD8 T cells. J Immunol 196: 3920-3926. doi:10.4049/jim munol.1502337

Sheridan BS, Pham QM, Lee YT, Cauley LS, Puddington L, Lefrançois L. 2014. Oral infection drives a distinct population of intestinal resident memory $\mathrm{CD} 8^{+} \mathrm{T}$ cells with enhanced protective function. Immunity 40: 747-757. doi:10.1016/j.immuni.2014.03.007

Shin H, Iwasaki A. 2012. A vaccine strategy that protects against genital herpes by establishing local memory T cells. Nature 491: 463-467. doi:10.1038/nature11522

Shinoda K, Hirahara K, Inuma T, Ichikawa T, Suzuki AS, Sugaya K, Tumes DJ, Yamamoto H, Hara T, Tani-Ichi S, et al. 2016. Thy $1^{+}$IL- $7^{+}$lymphatic endothelial cells in iBALT provide a survival niche for memory T-helper cells in allergic airway inflammation. Proc Natl Acad Sci 113: E2842-E2851. doi:10.1073/pnas.1512600113

Shiow LR, Rosen DB, Brdičková N, Xu Y, An J, Lanier LL, Cyster JG, Matloubian M. 2006. CD69 acts downstream of interferon- $\alpha / \beta$ to inhibit S1P1 and lymphocyte egress from lymphoid organs. Nature 440: 540-544. doi:10 $.1038 /$ nature04606

Shwetank, Abdelsamed HA, Frost EL, Schmitz HM, Mockus TE, Youngblood BA, Lukacher AE. 2017. Maintenance of PD-1 on brain-resident memory CD8 T cells is antigen independent. Immunol Cell Biol 95: 953-959. doi:10 $.1038 /$ icb. 2017.62

Skon CN, Lee JY, Anderson KG, Masopust D, Hogquist KA, Jameson SC. 2013. Transcriptional downregulation of S1pr1 is required for the establishment of resident memory CD8 ${ }^{+}$T cells. Nat Immunol 14: 1285-1293. doi:10 1038/ni.2745

Slütter B, Pewe LL, Kaech SM, Harty JT. 2013. Lung airwaysurveilling CXCR $3^{\text {hi }}$ memory $\mathrm{CD} 8^{+} \mathrm{T}$ cells are critical for protection against influenza A virus. Immunity 39: 939948. doi:10.1016/j.immuni.2013.09.013

Slütter B, Van Braeckel-Budimir N, Abboud G, Varga SM, Salek-Ardakani S, Harty JT. 2017. Dynamics of influenzainduced lung-resident memory $\mathrm{T}$ cells underlie waning heterosubtypic immunity. Sci Immunol 2: eaag2031. doi:10.1126/sciimmunol.aag2031

Smith CJ, Caldeira-Dantas S, Turula H, Snyder CM. 2015 Murine CMV infection induces the continuous produc- tion of mucosal resident T cells. Cell Rep 13: 1137-1148. doi:10.1016/j.celrep.2015.09.076

Snyder ME, Finlayson MO, Connors TJ, Dogra P, Senda T, Bush E, Carpenter D, Marboe C, Benvenuto L, Shah L, et al. 2019. Generation and persistence of human tissueresident memory T cells in lung transplantation. Sci Immunol 4: eaav5581.

Stark R, Wesselink TH, Behr FM, Kragten NAM, Arens R, Koch-Nolte F, van Gisbergen K, van Lier RAW. 2018. $T_{R M}$ maintenance is regulated by tissue damage via P2RX7. Sci Immunol 3: eaau1022. doi:10.1126/sciimmunol.aau1022

Stary G, Olive A, Radovic-Moreno AF, Gondek D, Alvarez D, Basto PA, Perro M, Vrbanac VD, Tager AM, Shi J, et al. 2015. A mucosal vaccine against Chlamydia trachomatis generates two waves of protective memory T cells. Science 348: aaa8205. doi:10.1126/science.aaa8205

Steinert EM, Schenkel JM, Fraser KA, Beura LK, Manlove LS, Igyártó BZ, Southern PJ, Masopust D. 2015. Quantifying memory CD8 T cells reveals regionalization of immunosurveillance. Cell 161: 737-749. doi:10.1016/j.cell.2015.03 .031

Strutt TM, Dhume K, Finn CM, Hwang JH, Castonguay C, Swain SL, McKinstry KK. 2018. IL-15 supports the generation of protective lung-resident memory CD4 T cells. Mucosal Immunol 11: 668-680. doi:10.1038/mi.2017.101

Suarez-Ramirez JE, Chandiran K, Brocke S, Cauley LS. 2019. Immunity to respiratory infection is reinforced through early proliferation of lymphoid $\mathrm{T}_{\mathrm{RM}}$ cells and prompt arrival of effector CD8 T cells in the lungs. Front Immunol 10: 1370. doi:10.3389/fimmu.2019.01370

Takamura S. 2018. Niches for the long-term maintenance of tissue-resident memory T cells. Front Immunol 9: 1214. doi:10.3389/fimmu.2018.01214

Takamura S, Kohlmeier JE. 2019. Establishment and maintenance of conventional and circulation-driven lung-resident memory $\mathrm{CD}^{+} \mathrm{T}$ cells following respiratory virus infections. Front Immunol 10: 733. doi:10.3389/fimmu .2019 .00733

Takamura S, Yagi H, Hakata Y, Motozono C, McMaster SR, Masumoto T, Fujisawa M, Chikaishi T, Komeda J, Itoh J, et al. 2016. Specific niches for lung-resident memory $\mathrm{CD}^{+} \mathrm{T}$ cells at the site of tissue regeneration enable CD69-independent maintenance. J Exp Med 213: 30573073. doi:10.1084/jem.20160938

Takamura S, Kato S, Motozono C, Shimaoka T, Ueha S, Matsuo K, Miyauchi K, Masumoto T, Katushima A, Nakayama T, et al. 2019. Interstitial-resident memory CD8 ${ }^{+}$ $\mathrm{T}$ cells sustain frontline epithelial memory in the lung. $J$ Exp Med 216: 2736-2747. doi:10.1084/jem.20190557

Teijaro JR, Turner D, Pham Q, Wherry EJ, Lefrançois L, Farber DL. 2011. Cutting edge: tissue-retentive lung memory CD4 T cells mediate optimal protection to respiratory virus infection. J Immunol 187: 5510-5514. doi:10.4049/jimmunol.1102243

Thom JT, Weber TC, Walton SM, Torti N, Oxenius A. 2015. The salivary gland acts as a sink for tissue-resident memory $\mathrm{CD}^{+} \mathrm{T}$ cells, facilitating protection from local cytomegalovirus infection. Cell Rep 13: 1125-1136. doi:10 $.1016 /$ j.celrep.2015.09.082

Thompson EA, Mitchell JS, Beura LK, Torres DJ, Mrass P, Pierson MJ, Cannon JL, Masopust D, Fife BT, Vezys V. 2019. Interstitial migration of CD8 $\alpha \beta$ T cells in the small 


\section{S. Takamura}

intestine is dynamic and is dictated by environmental cues. Cell Rep 26: 2859-2867.e4. doi:10.1016/j.celrep .2019 .02 .034

Topham DJ, Reilly EC. 2018. Tissue-resident memory CD8 ${ }^{+}$ T cells: from phenotype to function. Front Immunol 9: 515. doi:10.3389/fimmu.2018.00515

Turner DL, Bickham KL, Thome JJ, Kim CY, D’Ovidio F, Wherry EJ, Farber DL. 2014. Lung niches for the generation and maintenance of tissue-resident memory T cells. Mucosal Immunol 7: 501-510. doi:10.1038/mi.2013.67

van Gisbergen KP, Kragten NA, Hertoghs KM, Wensveen FM, Jonjic S, Hamann J, Nolte MA, van Lier RA. 2012. Mouse Hobit is a homolog of the transcriptional repressor Blimp-1 that regulates NKT cell effector differentiation. Nat Immunol 13: 864-871. doi:10.1038/ni.2393

Verbist KC, Field MB, Klonowski KD. 2011. Cutting edge: IL-15-independent maintenance of mucosally generated memory CD8 T cells. J Immunol 186: 6667-6671. doi:10 .4049/jimmunol.1004022

Wakim LM, Woodward-Davis A, Bevan MJ. 2010. Memory $\mathrm{T}$ cells persisting within the brain after local infection show functional adaptations to their tissue of residence. Proc Natl Acad Sci 107: 17872-17879. doi:10.1073/pnas .1010201107

Wakim LM, Woodward-Davis A, Liu R, Hu Y, Villadangos J, Smyth G, Bevan MJ. 2012. The molecular signature of tissue resident memory CD8 T cells isolated from the brain. J Immunol 189: 3462-3471. doi:10.4049/jimmu nol.1201305

Wakim LM, Smith J, Caminschi I, Lahoud MH, Villadangos JA. 2015. Antibody-targeted vaccination to lung dendritic cells generates tissue-resident memory CD8 T cells that are highly protective against influenza virus infection. Mucosal Immunol 8: 1060-1071. doi:10.1038/mi.2014 .133

Walsh DA, Borges da Silva H, Beura LK, Peng C, Hamilton SE, Masopust D, Jameson SC. 2019. The functional requirement for CD69 in establishment of resident memory
$\mathrm{CD}^{+} \mathrm{T}$ cells varies with tissue location. J Immunol 203: 946-955. doi:10.4049/jimmunol.1900052

Watanabe R, Gehad A, Yang C, Scott LL, Teague JE, Schlapbach C, Elco CP, Huang V, Matos TR, Kupper TS, et al. 2015. Human skin is protected by four functionally and phenotypically discrete populations of resident and recirculating memory T cells. Sci Transl Med 7: 279ra39. doi:10.1126/scitranslmed.3010302

Wilk MM, Misiak A, McManus RM, Allen AC, Lynch MA, Mills KHG. 2017. Lung CD4 tissue-resident memory T cells mediate adaptive immunity induced by previous infection of mice with Bordetella pertussis. J Immunol 199: 233-243. doi:10.4049/jimmunol.1602051

Worthington JJ, Kelly A, Smedley C, Bauché D, Campbell S, Marie JC, Travis MA. 2015. Integrin $\alpha v \beta 8$-mediated TGF- $\beta$ activation by effector regulatory T cells is essential for suppression of T-cell-mediated inflammation. Immunity 42: 903-915. doi:10.1016/j.immuni.2015.04.012

Yoshizawa A, Bi K, Keskin DB, Zhang G, Reinhold B, Reinherz EL. 2018. TCR-pMHC encounter differentially regulates transcriptomes of tissue-resident CD8 T cells. Eur J Immunol 48: 128-150. doi:10.1002/eji.201747174

Zaid A, Mackay LK, Rahimpour A, Braun A, Veldhoen M, Carbone FR, Manton JH, Heath WR, Mueller SN. 2014. Persistence of skin-resident memory $\mathrm{T}$ cells within an epidermal niche. Proc Natl Acad Sci 111: 5307-5312. doi:10.1073/pnas.1322292111

Zammit DJ, Turner DL, Klonowski KD, Lefrançois L, Cauley LS. 2006. Residual antigen presentation after influenza virus infection affects CD8 T cell activation and migration. Immunity 24: 439-449. doi:10.1016/j.immuni.2006 .01 .015

Zhang N, Bevan MJ. 2013. Transforming growth factor- $\beta$ signaling controls the formation and maintenance of gut-resident memory $\mathrm{T}$ cells by regulating migration and retention. Immunity 39: 687-696. doi:10.1016/j .immuni.2013.08.019 


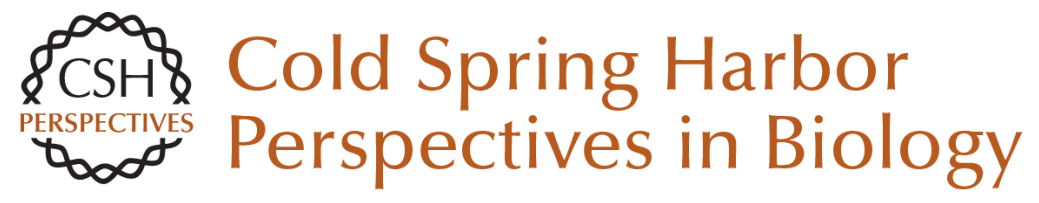

\section{Divergence of Tissue-Memory T Cells: Distribution and Function-Based Classification}

Shiki Takamura

Cold Spring Harb Perspect Biol 2020; doi: 10.1101/cshperspect.a037762 originally published online August 18, 2020

\section{Subject Collection T-Cell Memory}

Defining the Molecular Hallmarks of T-Cell

Memory

Caitlin C. Zebley, Rama S. Akondy, Benjamin A. Youngblood, et al.

Evolving Views of Long Noncoding RNAs and Epigenomic Control of Lymphocyte State and Memory

Tasha A. Morrison, William H. Hudson, Danielle A. Chisolm, et al.

Temporal and Epigenetic Control of Plasticity and Fate Decision during CD8 + T-Cell Memory

Differentiation

Luigia Pace

Durable CD4 T-Cell Memory Generation Depends on Persistence of High Levels of Infection at an Effector Checkpoint that Determines Multiple Fates

Susan L. Swain, Michael C. Jones, Priyadharshini Devarajan, et al.

Decoding Tissue-Residency: Programming and

Potential of Frontline Memory T Cells Simone L. Park and Laura K. Mackay

A Single-Cell Perspective on Memory T-Cell Differentiation

Lorenz Kretschmer, Dirk H. Busch and Veit R. Buchholz
Transcriptional Control of Cell Fate Determination

in Antigen-Experienced CD8 T Cells

Shanel Tsuda and Matthew E. Pipkin

CD4+ Memory T-Cell Formation during Type 1 Immune Responses

Peter D. Krueger, Kevin C. Osum and Marc K. Jenkins

CD8 ${ }^{+}$T-Cell Memory: The Why, the When, and the How

Stephen J. Turner, Taylah J. Bennett and Nicole L. La Gruta

How to Reliably Define Human CD8+ T-Cell

Subsets: Markers Playing Tricks

Michiel C. van Aalderen, Rene A.W. van Lier and Pleun Hombrink

Memory T-Cell Heterogeneity and Terminology

Yuki Muroyama and E. John Wherry

Homeostasis of Naive and Memory $\mathrm{T}$

Lymphocytes

Takeshi Kawabe, Jaeu Yi and Jonathan Sprent

For additional articles in this collection, see http://cshperspectives.cshlp.org/cgi/collection/

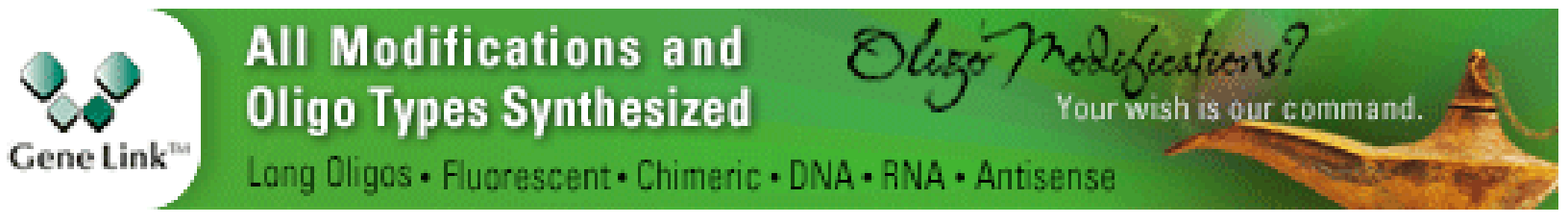

Copyright @ 2020 Cold Spring Harbor Laboratory Press; all rights reserved 


\section{Formation of Tissue-Resident CD8 ${ }^{+} \mathrm{T}$-Cell Memory}

Feline E. Dijkgraaf, Lianne Kok and Ton N.M. Schumacher

Homeostasis and Durability of T-Cell Memory-The Resting and the Restless T-Cell Memory Andreas Radbruch, Mairi Anne McGrath, Francesco Siracusa, et al.
Motility Matters: How CD8+ T-Cell Trafficking Influences Effector and Memory Cell

Differentiation

Yagmur Farsakoglu, Bryan McDonald and Susan M. Kaech

A Regenerative Perspective on Successful and Failed T-Cell Immunity Steven L. Reiner

For additional articles in this collection, see http://cshperspectives.cshlp.org/cgi/collection/

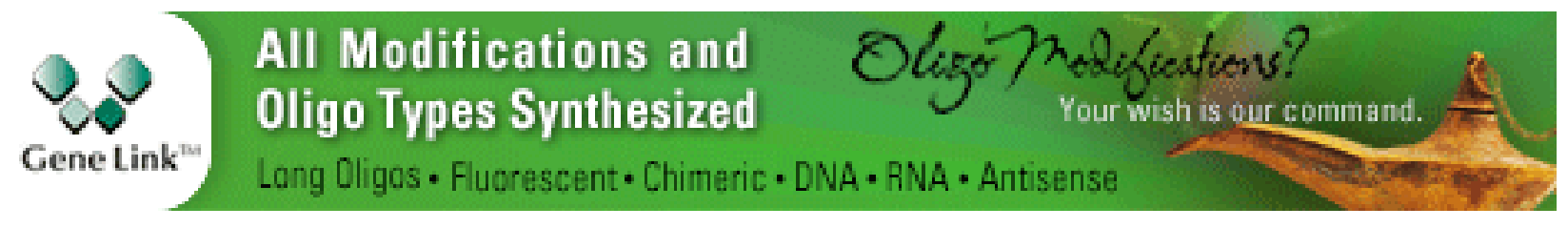

Copyright @ 2020 Cold Spring Harbor Laboratory Press; all rights reserved 